\title{
ASSESSING PRESENT AND FUTURE MEDITERRANEAN SEA LEVEL RISE IMPACT ON ISRAEL'S COAST AND MITIGATION WAYS AGAINST BEACH AND CLIFF EROSION
}

\author{
Sergiu Dov Rosen ${ }^{1}$, Member ASCE
}

\begin{abstract}
This paper presents the outcome of a coastal engineering hydro and morpho-dynamic model study using a number of numerical models which was conducted by the author on the erosion state of the Mediterranean coast of Israel for a time horizon of 100 years. The study assessed future sea levels, and compared wave setup and runup and beach profile erosion at the coastal cliffs in order to determine the relative sensitivity of the various coastal sectors of the Israeli shore. Finally it investigated measures and means for effective the mitigation of the forecasted beach and cliff erosion. The study was carried out as part of a multi disciplinary work involving various additional disciplines, and was used to establish a national policy document in regards to the coastal cliffs collapse and erosion by natural and anthropogenic induced factors, including global warming induced sea level rise and reduced return period of extreme events. The approach and outcomes are estimated to be useful for coasts of similar conditions elsewhere on the globe.
\end{abstract}

Keywords: sea level rise; wave setup; erosion; cliffs; wave climate;

\section{Introduction}

The present state of the Mediterranean coast of Israel is characterized as being in a mild erosive state, evidencing beach erosion and coastal cliffs retreat. The forecasted sea level rise induced by global warming, confirmed also in the Mediterranean, as well as the forecasted increase in the frequency of extreme storm conditions induced by climate change impact on wind and wave climate statistics, as well as the recent awareness of tsunami hazard in the Mediterranean, pose a joint hazard to this coastal sector. The coastal sector is the last and northern part of the Nile littoral cell, extending from the Nile delta throughout the bay of Haifa, being characterized by a major, beaches and nearshore quartz sand content (Fig. 1). The sand was originally brought until 1965 by the Nile river to its delta, when it stopped coming due to the completion of the high Aswan dam then. Nevertheless, the huge amount of sand which accumulated there has been continuously transported by the net joint actions of the waves, wind and currents partly offshore and partly eastward along the Sinai coast and then further northward on the Israeli coast until its end at Haifa bay up to Acre, both within and beyond the surf zone. On its alongshore way, some sand volume has been transported inshore to the beach and then to coastal dunes by the wind blowing on the beaches, some moved offshore beyond the closure depth and accumulated on the sea bottom profile and some moved further towards Haifa bay. At the same time, the coastal cliffs, which are present in the sector from Gaza to Hadera, have been eroding and retreating, providing an additional input to the total sand balance.

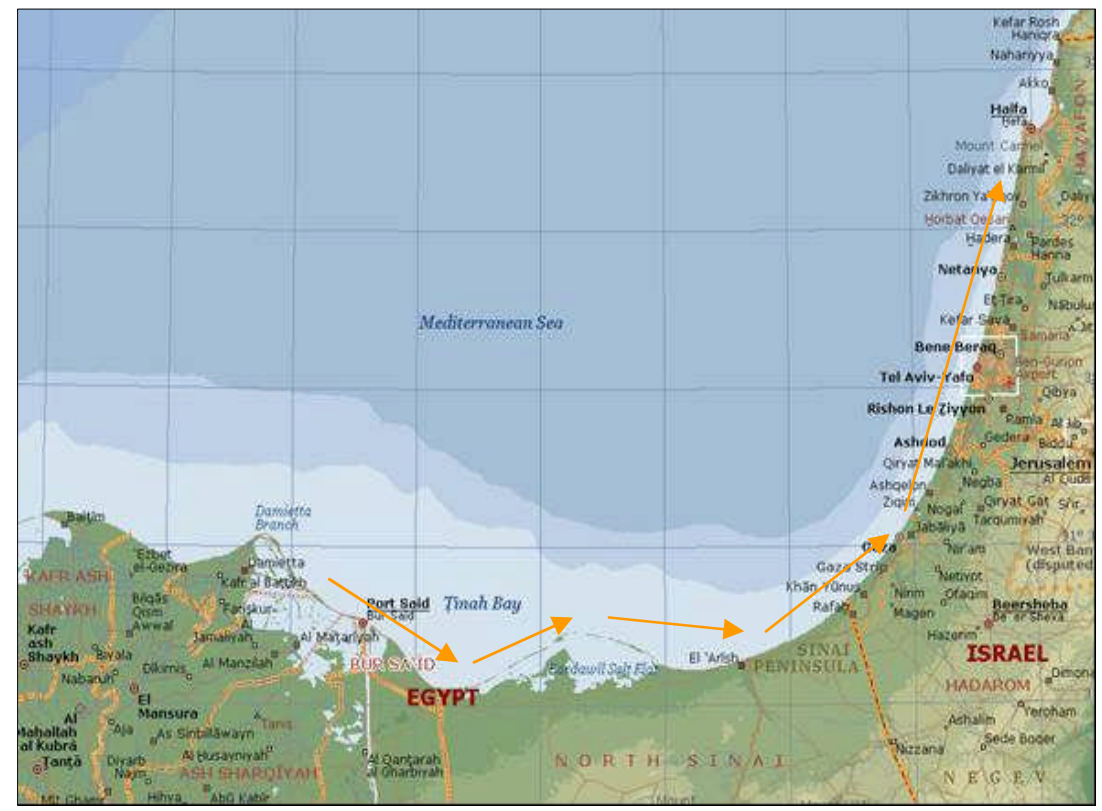

Fig. 1. Nile littoral cell location map (arrows indicate net longshore sediment transport direction)

\footnotetext{
${ }^{1}$ Department of Marine Geology \& Coastal Processes, National Institute of Oceanography of Israel Oceanographic \& Limnological Research, Tel Shikmona POB 8030, Haifa, 31080, Israel
} 
Recent severe beach and cliff erosion encountered at a number of locations along the Israeli coast (Figures 2 -5) led to the necessity to investigate and assess the present and future impact of climate change induced sea level rise as well as the optimum mitigating means against beach and cliff erosion, as part of the preparation of a National Policy Plan for Coastal Cliffs Management (recently approved by the Israeli Government), within a multi disciplinary study, jointly with other geological, planning, engineering, social and law bodies and consultants.
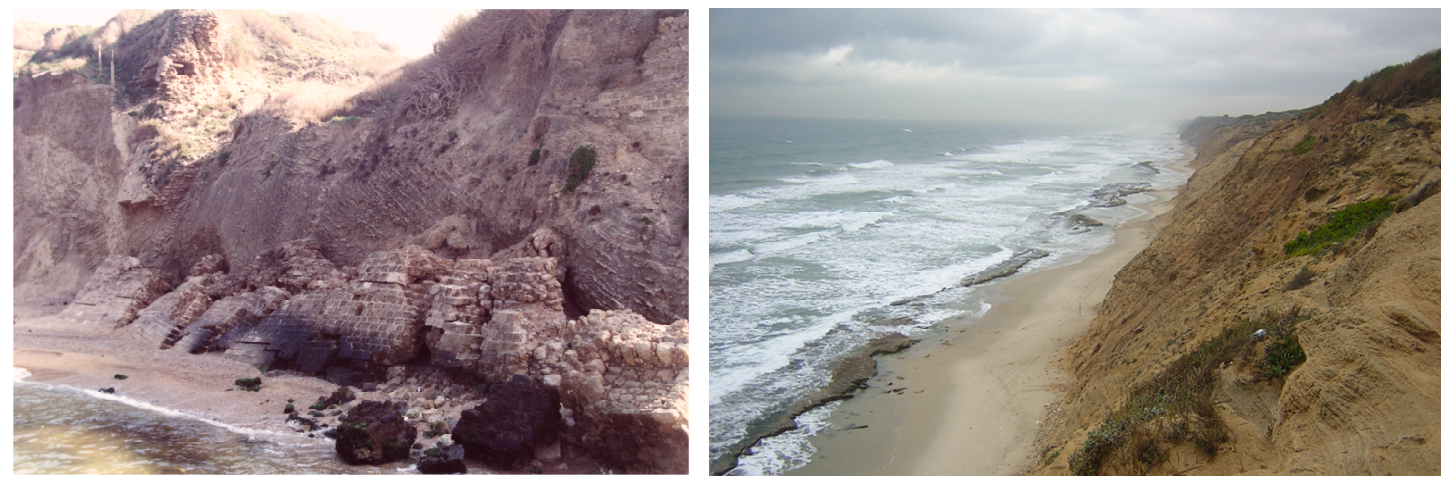

Figure 2. Collapse of the Apolonia fortress wall at Figure 3. Cliff and beach erosion during mild waves at Herzliya due to severe beach and cliff erosion Hasharon coastal sector
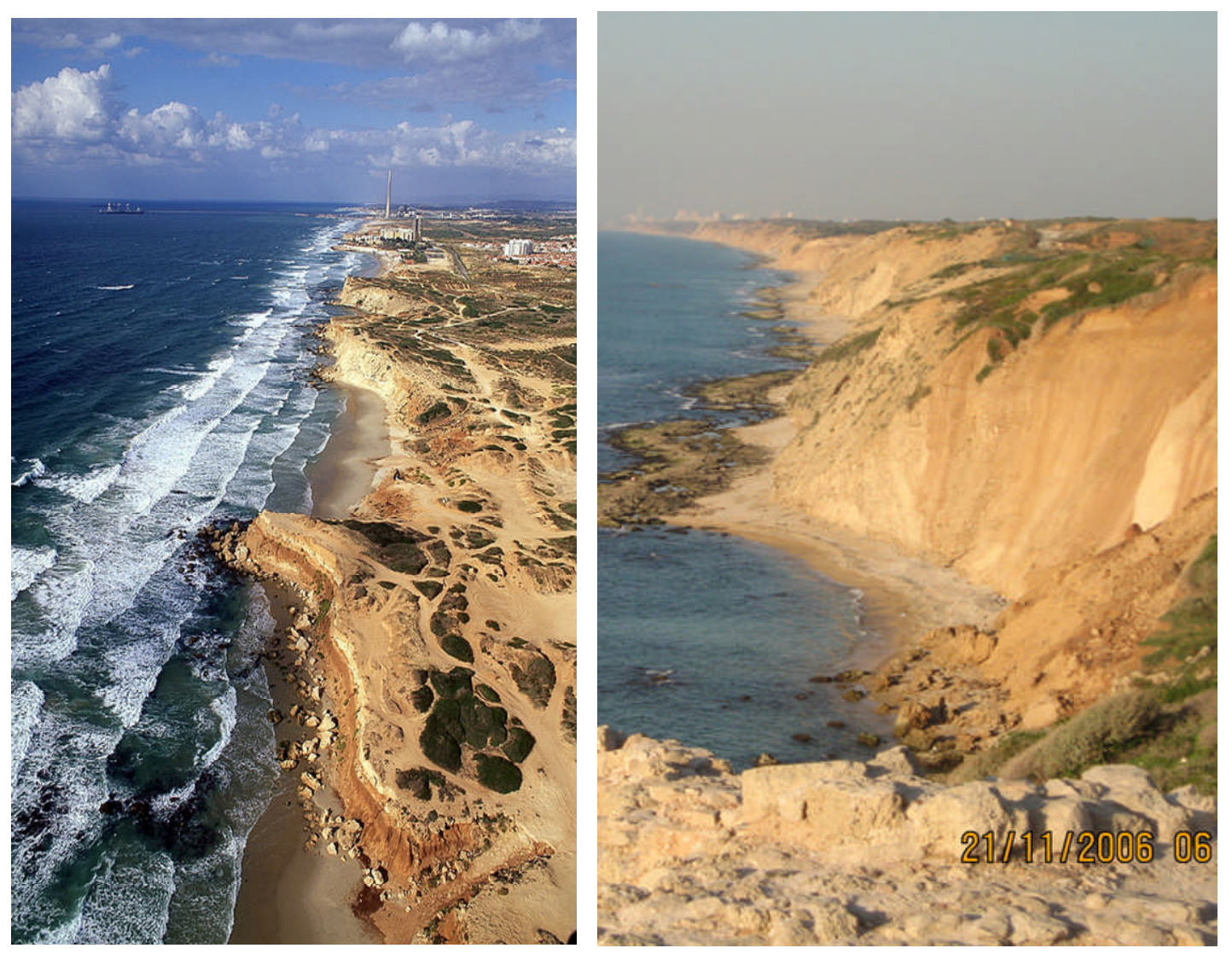

Figure 4. Beach and cliff erosion at Havazelet Figure 5. Cliff collapse at Herzliya coast north of Hasharon coastal sector north of Netanya

Apolonia ancient fortress

The Israeli Mediterranean coast is in a state of mild erosion expressed by beach and cliff set back due to anthropogenic past actions of sand beach mining and coastal development.. The present and future sea level rise due to global warming, the forecasted increased frequency of extreme storms induced by climate change on wind and wave statistics, and the confirmed serious tsunami hazard in the Mediterranean, imposed studying the sensitivity of this coastal sector to the above impacts up to 
2100, and to evaluate the needed ICZM policy of coastal engineering mitigation means to be implemented. While a number of methods and tools have been developed for such assessment, such as the DIVA model (DINAS-COAST Consortium, 2004; Hinkel, 2005), or by just assessing the flooded areas for certain sea level rise elevations (e.g. Clus-Auby et al. 2004) or even more sophisticate numerical tools such as sedimentological $2 \mathrm{Dh}$ or $3 \mathrm{D}$ commercial models were available on the market (Delft 3D, MIKE 21, etc.), the funding for the study was very limited while the goal was to obtain reliable results. Alternative assessment methods considered were:

a) Assessment of future sea levels including its rise by climate change, tide and future extreme wave and wind induced sea levels and marking of the positions of the various elevations on a topographic chart of the coast (simple approach).

b) As above combined with a full $2 \mathrm{D}$ detailed sedimentological model and a parallel qualitative study of the relative strength and stability of the coastal cliffs and utilization of global climate model forecasts in study area (difficult).

c) As a) in combination with a storm profile development model of typical coastal sectors and with a detailed wave transformation and setup model along all the coast and a parallel study of the relative strength and stability of the coastal cliffs (moderate). This method, imposing the selection of a more simplistic approach, which, nevertheless was estimated to enable yet reaching reasonably correct assessment of future expected impact and effectiveness of mitigating means and was selected for the present study.

\section{Scope of the study}

The investigation conducted consisted of:

1.Analysis of the present state of the Israeli coast in regards to beach and coastal cliff erosion by performing differential high resolution volumetric maps of the shore and cliffs erosion and accretion, induced by both natural and anthropogenic activities (not presented in this paper),

2.An updated analysis of the directional wave climate, of the local and regional sea level changes and an assessment of future changes of the meteo-marine statistics and the resulting coastal erosion for a time horizon of 100 years under future sea level rise and wave statistics change scenarios. This has been performed using various modelling tools such as the hydrodynamic wave propagation model SWAN ver. 4 (Holthuijsen et al. 2007), the Cross shore model SBEACH (Sommerfeld et al. 1996) as well as additional tools included in the CEDAS software package version 4.03 Pro (Veritech Inc. 2006), in order to assess the future coast erosion along the coast and determine the most sensitive coastal sectors. A bathymetric and topographic grid with a cell size of $5 \mathrm{~m}$ has been prepared for 3 coastal sectors covering most of the coastal cliffs along the Mediterranean coast of Israel, for a total length of about $60 \mathrm{~km}$. An exception were the coastal sector north of Poleg river, were the existing bathymetric data were found to contain many unreliable data. However, the results obtained for the other sectors enabled to make estimates also about this shorter coastal sector which was not modelled.

3.Analysis of a number of types of coastal erosion mitigating means (e.g. submerged breakwaters, submerged underwater reefs, etc.) and

4.Re-modelling of typical coastal sectors with various mitigation means for the same time horizon.

\section{Investigation program}

The IOLR investigation was composed of:

- Assessment of past \& present coastal beach and cliff erosion (extent and rates) by differential charts and water line retreat,

-Assessment of future sea level rise and selection of wave climate scenarios for a time span horizon up to 2100 ,

- Simulations of wave action on coastal sectors with exposed cliffs using the SWAN model on a $10 \mathrm{~m} X$ $10 \mathrm{~m}$ grid cell size and by comparative investigation of the wave setup and runup, to rank the most endangered coastal sectors,

- Simulation of cliff erosion using storm profile change sedimentological model SBEACH at $1 \mathrm{~km}$ intervals using a $5 \mathrm{~m}$ grid cell and various storm scenarios for up to 2100 , in order to assess the relative potential beach and cliff erosion at the various coastal cliff sectors, assuming sandy cliffs.

- The relative state of coastal sectors located between the sections investigated in SBEACH was determined using the relative percentage of time and extent the cliff toe was estimated to be attacked for the time horizon of 10, 20, 50 and 100 years by wave induced setup and run-up, derived using the SWAN model. 
- Finally, using the meteomarine climate observed in the last decade, the future coastal cliff recess rate was assessed, by comparing the recession rate determined in the model assessment for the last decade versus the outcome of field monitoring of quantitative cliff recess at the various coastal sectors in the same 10 years period, combined with the relative strenght and stability of the cliffs as determined by the other parallel studies.

\section{Assessment of the wave setup and runup at the cliff during present and future sea level rise}

While the $3^{\text {rd }}$ Intergovernmental Panel on Climate Change Assessment (IPCC. 2001) of surface temperature \& sea level rise until 2100 for Bussiness As Usual scenario (BAU) provided the following estimates of global sea level rise of up to $0.89 \mathrm{~m}$ by 2100 , lower estimates were derived by $4^{\text {th }}$ IPCC assessment (IPCC. 2007) shown in table 1.

\begin{tabular}{|c|c|c|c|}
\hline \multicolumn{4}{|c|}{ Table 1. Estimates of future sea level rise by IPCC 2001, IPCC 2007 and Rahmstorf 2006} \\
\hline Assessor & IPCC 2001 & IPCC 2007 & Rahmstorf (2006) \\
\hline Year & & & $+10 \mathrm{~cm}$ to $+20 \mathrm{~cm}$ \\
\hline 2025 & $+3 \mathrm{~cm}$ to $14 \mathrm{~cm}$ & & $+20 \mathrm{~cm}$ to $+40 \mathrm{~cm}$ \\
\hline 2050 & $+5 \mathrm{~cm}$ to $35 \mathrm{~cm}$ & & $+50 \mathrm{~cm}$ to $+135 \mathrm{~cm}$ \\
\hline 2100 & $+9 \mathrm{~cm}$ to $89 \mathrm{~cm}$ & $+0.26 \mathrm{~cm}$ to $+0.59 \mathrm{~cm}$ & \\
\hline
\end{tabular}

The sea level rise forecast of IPCC 2007 was criticised as misleading by a number of recent studies, which showed that there is potential for sea level rise beyond $+1.0 \mathrm{~m}$ by 2100 . The main reasoning was that the IPCC 2007 assessment did not account for the ice cover melting. These assessments were compared also against the local sea level rise trends at the GLOSS station 80 Hadera, operated by IOLR. The most recent results are shown in Figure 6. The rise trend indicated that the local sea level rise is slightly higher than the global measured values (at present about $5.8 \mathrm{~mm} / \mathrm{year}$ vs the global average of almost $4 \mathrm{~mm} / \mathrm{year}$ ), so it was decided to select a sea level rise of $+100 \mathrm{~cm}$ by 2100 for the Israeli coast.

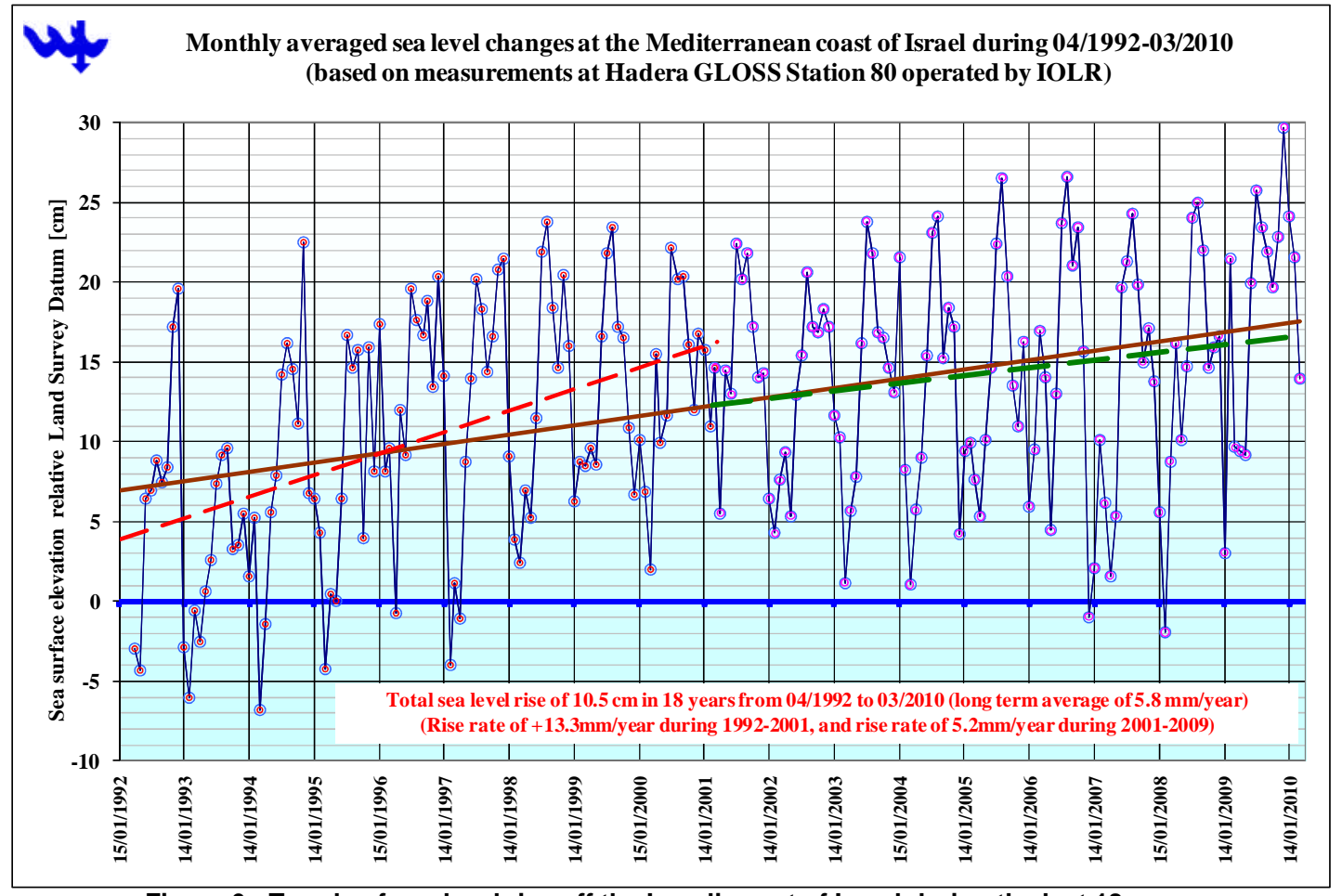

Figure 6 - Trends of sea level rise off the Israeli coast of Israel during the last 18 years

As shown by a number of recent studies (Rahmstorf. 2006/2007; Grinsted et al. 2009; Vermeer and Rahmstorf. 2009; Vellinga et al. 2009; Jevrejeva et al. 2010; Rahmstorf. 2010) the sea level rise by 2100 is considered to be able to exceed $100 \mathrm{~cm}$. Consequently the accepted sea level rise for the Israeli coast seems to be reasonable, and the simulations were based on a linear sea level rise from 2000 to 2100. Return periods of extreme sea levels were also assessed, and based on these the computed values 
were derived for the sea level at the cliff position, as indicated in Table 2. The extreme sea states and the resulting sea levels and run-up at the cliff are shown in Figure 10 and the simulated sea states are represented in Table 3 and in Table 4 are provided the sea conditions tested with SWAN

\begin{tabular}{|l|l|l|}
\hline $\begin{array}{l}\text { Table 2. Sea levels statistics at Israel shore, based on 19 years hourly average levels gathered at } \\
\text { Ashdod port and their separation into astronomic tide and meteorological residuals }\end{array}$ \\
\hline \multicolumn{2}{|c|}{ Period: during 1966-1984 } & date \\
\hline Max sea level (cm) & 93.0 & 22.12 .1967 \\
\hline Min sea level (cm) & -53.0 & 09.01 .1977 \\
\hline Max astronomic tide in 19 years HAT (cm) & 44.5 & 07.08 .1967 \\
\hline Min astronomic tide in 19 years LAT (cm) & -36.4 & 04.03 .1976 \\
\hline Max high surge level (cm) & 70.7 & 22.12 .1967 \\
\hline Min lowering sea level by winds (cm) & -42.9 & 15.12 .1971 \\
\hline
\end{tabular}

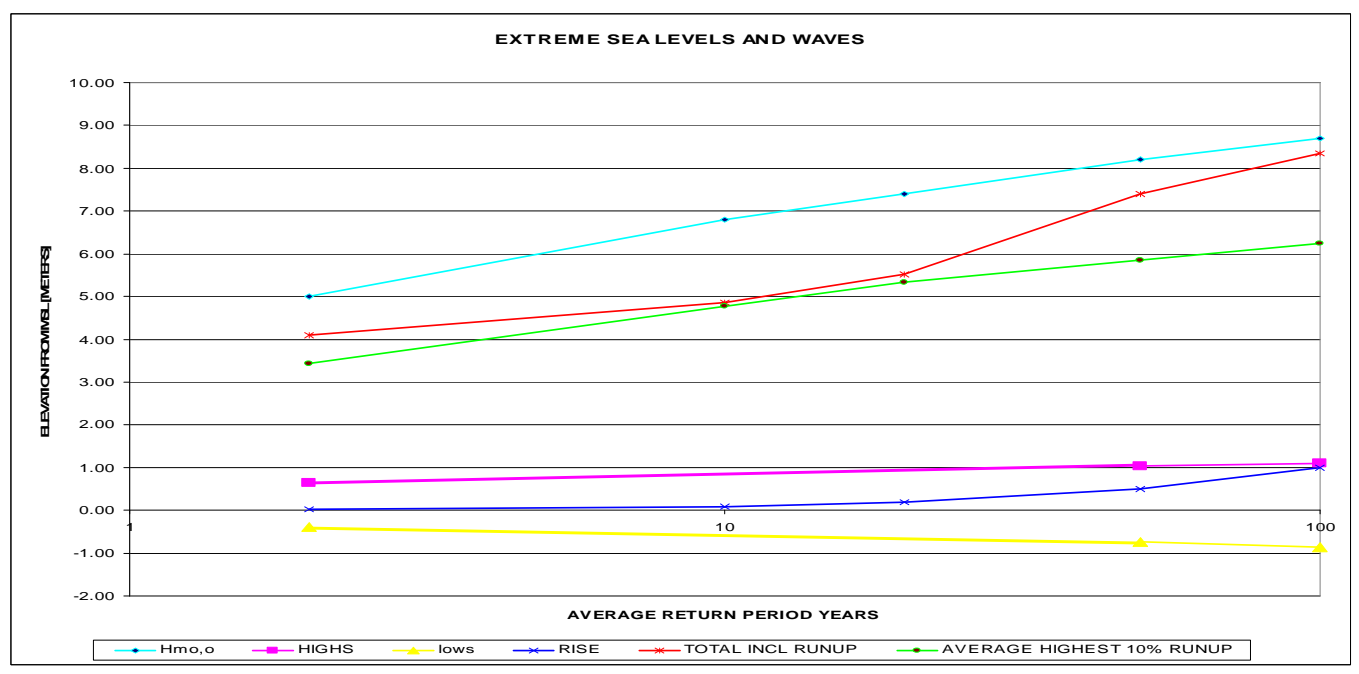

Figure 9. Extreme water levels and sea states assessed for the study prior to the SWAN modelling

\begin{tabular}{|ccccc|}
\hline $\begin{array}{c}\text { Deep Wave } \\
\text { direction Az } \\
\text { deg }\end{array}$ & $\begin{array}{c}\text { Water level } \\
\text { (m) vs ILSD }\end{array}$ & Hs, $\mathbf{0}(\mathbf{m})$ & Tp(sec) $\mathbf{=} \mathbf{5 . 4 5}^{\star}(\mathbf{H s}, \mathbf{0})^{\wedge} \mathbf{0 . 5}$ & duration( hours) \\
270 & 0 & 2 & 7.68 & \\
270 & 0.10 & 3.00 & 9.44 & 12.80 \\
270 & 0.20 & 4.00 & 10.90 & 12.80 \\
270 & 0.30 & 5.00 & 12.19 & 10.60 \\
270 & 0.40 & 6.00 & 13.35 & 10.40 \\
270 & 0.60 & 7.00 & 14.42 & 10.30 \\
270 & 1.00 & 8.00 & 15.41 & 9.00 \\
270 & 1.00 & 9.00 & 16.35 & 3.00 \\
270 & 1.00 & 10.00 & 17.23 & 3.00 \\
270 & 1.00 & 11.00 & 18.08 & 3.00 \\
\hline
\end{tabular}

\begin{tabular}{|ccccc|}
\hline \multicolumn{2}{c}{ Table 4. Sea conditions run with SWAN } \\
Sea level & Sea state duration & $\mathbf{T}_{\mathbf{p}}$ & $\mathbf{H}_{\mathbf{s}, \mathbf{0}}$ & Return period \\
$\mathrm{m}$ & hours & $\mathrm{sec}$ & $\mathrm{m}$ & years \\
0.0 & 13.1 & 11.5 & 4.80 & 1 \\
0.0 & 10.4 & 13.0 & 6.15 & 5 \\
$0.0 ;+0.1$ & 10.2 & 13.5 & 6.80 & 10 \\
$0.0 ;+0.2$ & 9.5 & 14.0 & 7.40 & 20 \\
$0.0 ;+0.5$ & 8.8 & 15.0 & 8.20 & 50 \\
$0.0 ;+1.0$ & 4.0 & 15.5 & 8.70 & 100 \\
\hline
\end{tabular}




\section{Results}

An example of the bathymetry and wave setup induced during various sea level rise conditions and sea states is shown in Figures 10 and 11.

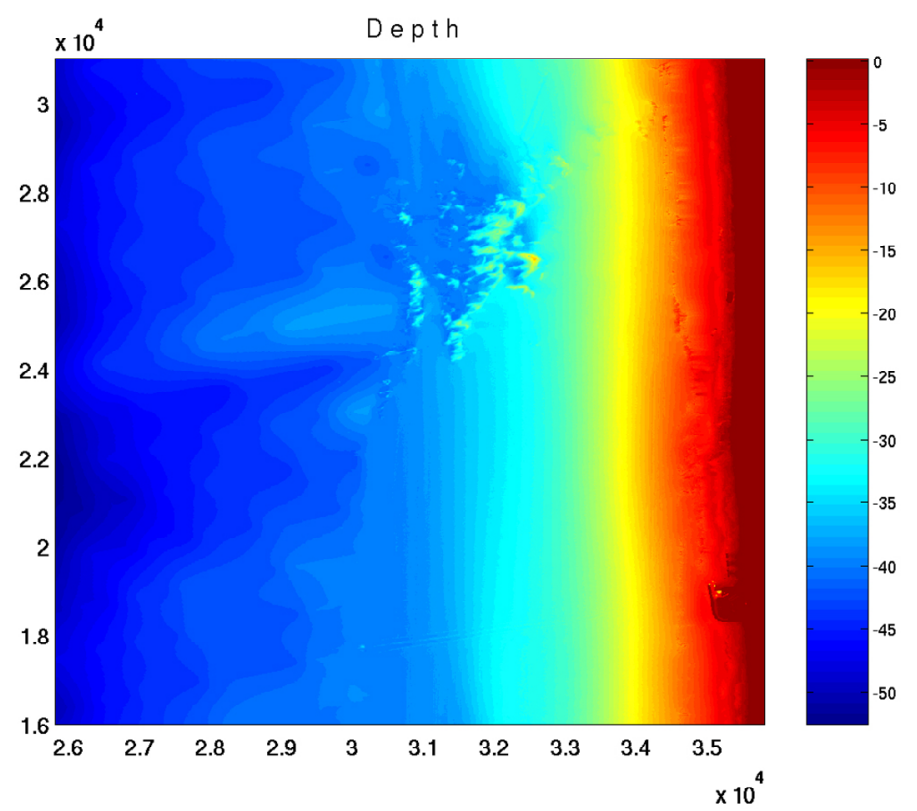

Figure 10. Central coastal sector northern part Bathymetric \& topographic chart

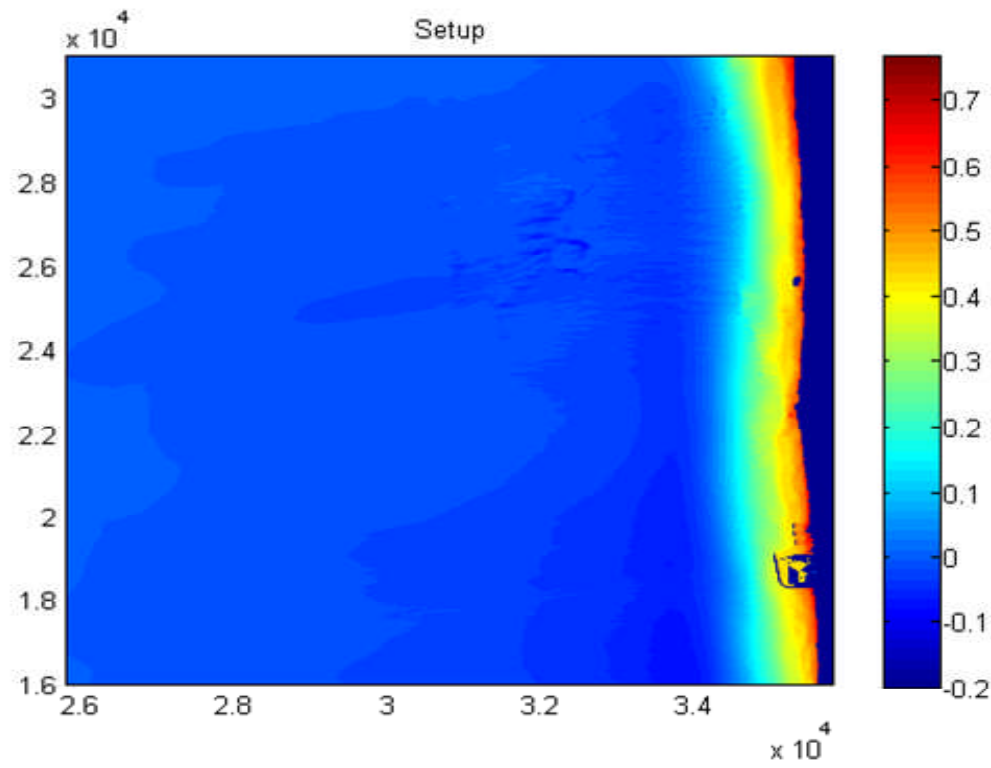

Figure 11. Central coastal sector - northern part - wave setup

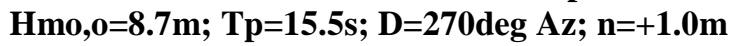

Example of results of the SBEACH outcomes are shown in Figure 12, 


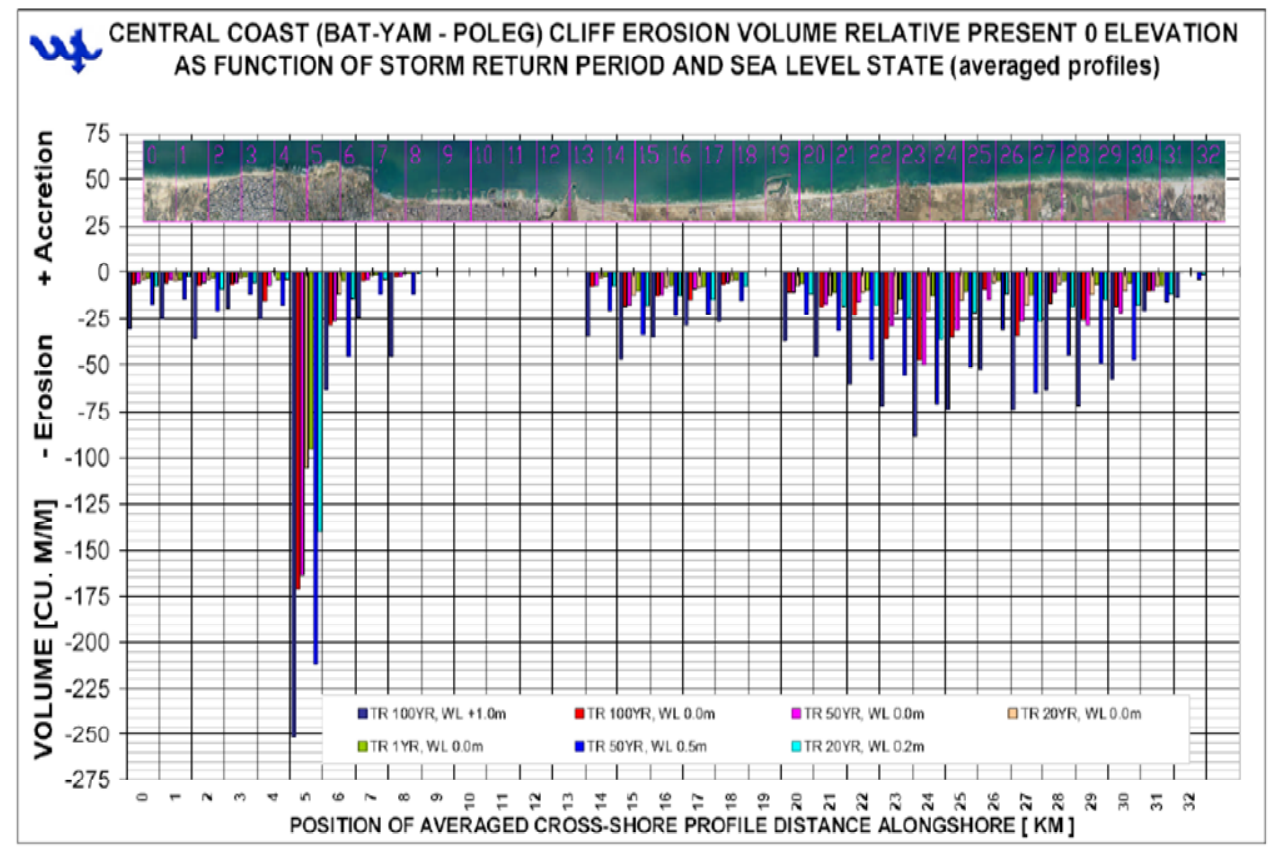

Figure 12. Example of SBEACH results for the same coastal sector

The outcome of the study conducted provided quantitative estimates of the beach and cliff erosion both as retreat rates and as volumetric rates, pinpointing the location of the coastal sectors with the highest rates of erosion expectancy (Figure 12). Analysis of the mitigation means led to the validation of the effectiveness of a new mitigation method against coastal erosion due to sea level rise and increased storminess. This mitigation consists of utilization of detached submerged breakwaters chains, with the tops near the MSL, located relatively remote from the original shoreline, well beyond the predominant surf zone, in combination with singular beach nourishment and cliff toe protection using sand filled geotextile sacks/geotubes. The mitigation is achieved by limiting the wave height at the beach and cliff toe due to the breakwaters chain, and compensation of the almost constant but low sea surface elevation $(\sim 0.5 \mathrm{~m})$ at the cliff toe by the sand nourishment of the beach face and protection of the cliff toe scouring by the sand filled geotextiles. The results are expected to be useful for design of effective coastal protection at similar coastal environments and of relatively low astronomic tide range, elsewhere in the world.

\section{ACKNOWLEDGMENTS}

The author wishes to express his gratitude to the following persons and bodies who enabled him in conducting of the reported study: Dr. J. K. Hall and Mr. R. Sade for providing high resolution multibeam bathymetry, Mr. A. Golan for preparing the bathymetric and topographic grid for the SWAN model; Dr. B. Galanti for adapting and running the SWAN wave simulations; Mr. L. Raskin for processing the Hadera sea level and wave data. The study was financially funded by the Ministry of the Environment Protection with additional funding from the American Friends of IOLR fund. Topographic high resolution data of the cliffs and beaches have been gathered within earlier coastal studies funded by the Ministry of Infrastructures.

\section{REFERENCES}

Almagor G., D. Gill, and I. Perath, 1998, Marine sand resources offshore Israel, Geological Survey of Israel, Report GSI/25/98, Jerusalem, September 1998.

Bowman D., D. Arad, D.S. Rosen, E. Kit, R. Goldbery, A. Szlavicz, 1988. Flow characteristics along the rip current system under low energy conditions, J. Marine Geology, No. 82, pp. 149-167.

Bowman D., H. Birkenfield, D.S. Rosen. 1992. The longshore flow component in low energy rip channels: The Mediterranean, Israel, Journal of Marine Geology, No. 108, pp. 259-274.

Caires, S., V. Swail, X. Wang. 2006. Projection and analysis of extreme wave climate, Journal of Climate.

Cavaleri L., and L. Bertotti. 2004. Accuracy of the modelled wind and wave fields in enclosed seas, Tellus, 56a, 167-175. (2004). 
Chen J., D. Eisma, K. Hotta and H.J. Walker. editors. 2002. Engineered coasts, Coastal systems and continental margins, Vol. 6, Kluver Academic Publ., Dordrecht, The Netherlands.

Church, J.A. et al., 2001, Changes in Sea Level. in: J.T. Houghton, editor: Climate Change 2001, The Scientific Basis, IPCC TAR Working Group I, Cambridge University Press., Cap. 11, pp. 639694.

Clus-Auby, C., R. Paskoff, F. Verger. 2004. Impact du changement climatique sur le patrimoine du conservatoire du littoral scénarios d'érosion et de submersion à l'horizon 2100 - Synthese, Conservatoire du littoral, France.

Dean R.G., and R.A.Dalrymple. 1992. Water wave mechanics for engineers and scientists, Advanced Series on Ocean Engineering, Vol. 2, World Scientific, $2^{\text {nd }}$ printing, Singapore.

Dean R.G. 1995. Cross-shore sediment transport processes, in Liu P.L.-F. editor: Advances in coastal and ocean engineering, Vol. 1, pp. 159-220, World Scientific Publ., Singapore

Delft Hydraulics. 1999. Assessment Of Morphological Impacts Due To Construction Of Artificial Islands Along The Coast Of Israel: Airport Island Between Tel Baruch and Herzliya, Ministry of Transport, Gov. of Israel.

DINAS-COAST Consortium. 2004. DIVA 1.0. Potsdam Institute for Climate Impact Research, Potsdam, Germany, CD-ROM.

DINAS-COAST Consortium. 2004. DIVA Dynamic Interactive Vulnerability Assessment User Manual, Potsdam Institute for Climate Impact Research, Potsdam, Germany.

Douglas B.C., M.S. Kearney, and S.P. Leatherman. 2001. Sea level rise history and consequences, International Geophysics Series, Vol. 75, Academic Press, San Diego, California, USA, 232pp.

Fenoglio-Marc L. 2001. Analysis and representation of regional sea-level variability from altimetry and atmospheric-oceanic data, Geophys. J. Int. (2001) 145, 1-18

Fenoglio-Marc L. 2002. Long term sea level changes in Mediterranean sea from multi-mission altimetry and tide gauges, EGS XXVI General Assembly, Nice, France, March 2001, Session G4.01.

Fenoglio-Marc L. and D.S. Rosen. 2004. Comparison of sea level changes in the last decade in the Mediterranean sea using satellite altimetry vs tide gauge data, Proc. $37^{\text {th }}$ CIESM Congress (Barcelona, 7-11 June 2004) (in print).

Fredsoe J. 1984. Turbulent boundary layer in wave-current motion, Journal of Hydraulic Research, Vol. 110, No. 8.

Goda Y. 2000. Random seas and design of maritime structures, Adv. Ser. on Ocean Engineering, Vol 15 , World Scientific, Singapore.

Goldsmith V., and A. Golik. 1980. Sediment transport model of the South-Eastern Mediterranean coast of Israel, Marine Geology, Vol. 37, pp.147-175.

Golik A., D.S. Rosen, V. Brachia. 1999. Management of Israeli Coastal Sand Resources, in CAMP Israel, Mediterranean Action Plan, UNEP and Israel Ministry of Environment, (also IOLR Report H28/1999, Haifa), November 1999

Golik A., D.S. Rosen, A. Golan, M. Shoshany, D. Dicastro, P. Harari. 1997. Ashdod port's effect on the shoreline, seabed and sediment, Proc. 25th ICCE, Orlando, USA, 1997, Vol. 4, Chap. 339, pp. 4376-4389, ASCE, NY, USA.

Grinsted A., J. C. Moore, S. Jevrejeva. 2009. Reconstructing sea level from paleo and projected temperatures 200 to 2100AD. Clim. Dyn., (http://dx.doi.org/10.1007/s00382-008-0507-2)

Hammad, H.Y., I. Mobarek, A.A. Khafagy, S. Sidky. 1979. A short note on the sediment regime of the river Nile, Bull. Inst. Oceanography and Fisheries, Alexandria, pp. 314-322.

Heidelore, I; P. Simonovic. 1997. Development Of A Risk Measure As A Sustainable Project Selection Criterion, The international journal of sustainable development and world ecology, vol. 1, no.4, pp. 274-285.

Herbich, J.B., A.E. Elfiky, G.H. El-Saeed. 1998. The morphological changes along the Northern coast of the Nile delta, Abstracts $26^{\text {th }}$ ICCE, June 1998, Copenhagen, Danmark, p.42.

Hinkel, J. 2005. DIVA: an iterative method for building modular integrated models, Advances in Geosciences, 4, 45-50, 2005.

Hinkel, J., and Richard J.T. Klein. 2006. Integrating Knowledge for Assessing Coastal Vulnerability to Climate Change, in L. McFadden, R.J. Nicholls and E.C. Penning-Rowsell, editors: Managing Coastal Vulnerability: An Integrated Approach, Elsevier Science, Amsterdam, The Netherlands.

Hinrichsen, D., 1998. Coastal Waters of the World: Trends, Threats, and Strategies, Washington, D.C., Island Press, 275 pp. 
Holthuijsen, L.H., Booij, N., Ris, R.C., Haagsma, IJ.G., Kieftenburg, A.T.M.M. and Padilla-Hernandez R. 1999. SWAN Cycle 3 version 40.41 USER MANUAL (not the short version), Delft University of Technology, Delft, The Netherlands, $117 \mathrm{p}$.

Horton, R., C. Herweijer, C. Rosenzweig, J. Liu, V. Gornitz, A. C. Ruane. 2008. Sea level rise projections for current generation CGCMs based on the semi-empirical method, Geophys. Res. Lett. 35, L02715. doi:10.1029/2007GL032486, 200

Inman D. L. and Bagnold R. A. 1963. Littoral processes, In M. N. Hill (Editor), The Sea: Ideas and Observations, v. 3. The Earth Beneath the Sea. Interscience Publishers, New York \& London, pp. 529-553.

Intergovernmental Panel on Climate Change, 2007. Climate Change 2007: The Physical Science Basis, Summary for Policymakers, Contribution of Working Group I to the 4th Assessment Report, IPCC Secretariat, c/o WMO, Geneva, SWITZERLAND, $21 \mathrm{p}$.

International Standards Organization. 2007. International standard ISO 21650: Actions from waves and currents on coastal structures, 1st ed., 15 Nov. 2007.

Jensen O.J. 1990. Report on hydraulic studies for the planned marina at Ashkelon, Seatech Consulting Engineers A/S Copenhagen.

Jevrejeva, S., J. C. Moore, A. Grinsted. 2010. How will sea level respond to changes in natural and anthropogenic forcings by 2100?, Geophysical research letters, Vol. 37, L07703, 5 pp.

Kamphuis J.W. 1998. Sedimentological Aspects for the Israeli Mediterranean Coast and for the Ashdod Port Expansion, J.W.Kamphuis Associates Ltd., Kingston, Canada, Rep. ISR-01, May 1998, 31 pp. (unpublished rep. to Min. of Envir.).

Kamphuis J.W. 2000. Introduction to coastal engineering and management, Adv. Ser. on Ocean Engineering, Vol 16, World Scientific, Singapore.

Katz, A., R. Benari, and G. Peterker. 2006. "Descriptive mapping of the coastal cliffs, identification of flooding planes due to sea level rise and preliminary scenario of the coastal cliff retreat, Geological Survey of Israel. (in Hebrew).

Kit E., and E. Pelinovsky. 1998. Dynamical models for cross-shore transport and equilibrium bottom profiles, JWPCOE, Vol. 124, No. 3, May/June 1998, pp. 138-146, ASCE.

Klein M. 1994. The formation and disappearance of a delta at the El-Arish river mouth, in: Galil B. and Mart Y., ed. "Abstr. $6^{\text {th }}$ yearly Symposium on the Mediterranean shelf of Israel", IOLR, Haifa, April 1994, 5pp (in Hebrew with English Summary).

Klein R.J.T., R.J., Nicholls S. Ragoonaden, M. Capobianco, J. Aston, E.N. Buckley. 2001. Technological options for adaptations to climate change in coastal zones, J. Coastal Research, Vol. 17, no. 3, pp. 531-543, Summer 2001.

Koerner R.M., 1997, Designing with geosyntethics, $4^{\text {th }}$ ed., Prentice-Hall Inc., USA

Kraus N.C and K.L. Rankin, ed., 2004, Functioning and design of coastal groins, J. Coastal Research Sp. Issue \#33, 2004.

McCarthy J.J., O.F. Canziani, N.A. Leary, D.J. Dokken, K.S. White, editors: Climate Change 2001, Impacts, Adaptation and Vulnerability, Working Group. II contribution to the Third Assessment Report of the Intergovernmental Panel on Climate Change, UNEP and WMO, Publ. by Cambrigde University Press, UK., 2001.

McConnell K. 1998. Revetment systems against wave attack - A design manual, Thomas Telford Publ., London, UK.

McHarg, I. L.. 1992. Design With Nature, John Wiley \& Sons, Inc, New-York.

Nicholls, R.J. 2004. Coastal flooding and wetland loss in the 21st century: changes under the SRES climate and socio-economic scenarios. Global Environmental Change. 14 (2004) 69-86.

Nir, Y. 1982. Offshore Artificial Structures And Their Influence On The Israel And Sinai Mediterranean Beaches, Geological Survey of Israel, Jerusalem.

Perath A., and G. Almagor. 1996. Hazards along the Hasharon coastal cliff. Geological Survey of Israel Report GSI/5/96 (in Hebrew).

Pilarczyk, K.W., R.B. Zeidler. 1996. Offshore Breakwaters And Shore Evolution Control, A. A. Balkema, Rotterdam.

Rahmstorf S. 2006. A Semi-Empirical Approach to Projecting Future Sea-Level Rise, Sciencexpress /www.sciencexpress.org/14 Dec. 2006, 10.1126/science.1135456, 8 p.

Rahmstorf, S. 2007. A Semi-Empirical Approach to Projecting Future Sea-Level Rise, Science 315, $368-370$.

Rahmstorf S. 2010. Has the IPCC underestimated the risk of sea level rise?, Nature reports climate change, Vol 4, April 6, 2010, www.nature.com/reports/climatechange 
Rosen D.S. 1993. Study of 50 years coastal changes at Hadera, Israel, Proc. 23rd International Conference on Coastal Engineering, Venice, October 1992, ASCE Publ., Vol. 3, Cap. 259, pp. 3399-3412.

Rosen D.S. 1997. Peninsulas - preferred alternative for the expansion and development of the coast of Israel, $9^{\text {th }}$ Yearly Symposium on the Study of the Mediterannean Coastal Shelf of Israel, ed. Galil B. and Y. Mart, IOLR, Haifa, June 1997, pp.12-18.(in Hebrew).

Rosen D.S. 1997. Physical aspects of the Mediterranean versus sustainable coastal and marine development, Proc. Intl. Forum on The Fragility of the Mediterranean Ecosystem, A Conflict of Uses and Resources, Vilanova i la Geltru,(Barcellona), Spain, 12-13 March 12-13,1997, 20pp.

Rosen D.S.. 1998. Assessment of marine environmental impacts due to construction of artificial islands on the coast of Israel, Progress Report No. 4, Characterization of the mete-oceanographic climate in the study sector, I.O.L.R. Report No. H16/98, Haifa, May 1998.

Rosen D.S. 1998. Assessment of marine environmental impacts due to construction of artificial islands on the coast of Israel, Progress report no. 6, Present sedimentological state assessment in the study sector, IOLR, Report No. H17/98, Haifa, September 1998.

Rosen D.S. 1998. The Wave Climate of the Territorial Waters of Israel in the Mediterranean Sea, IOLR, Report No. H36/98, Haifa, October 1998.(in Hebrew).

Rosen D.S. 1999. Consultation regarding the dredging and sand by-passing from south to Ashdod port, north to the port and the necessary monitoring, IOLR Report H22/1999, August 1999, (in Hebrew).

Rosen D.S. 2000. Assessment of the existing sedimentological state at the coast of Israel, Abstracts 27th International Conference on Coastal Engineering, Vol. 2, Poster No.44, July 16-21, 2000, Sydney, Australia, ASCE Publ.

Rosen D.S. 2001. Consultation regarding the environmental impact statement of Beit Yanai beach cliff plan AH/MK133/4, in regards to coastal engineering aspects, Israel Oceanographic \& Limnological Research, Tel Shikmona, Haifa, IOLR Report H06/2001, April 2001, (in Hebrew).

Rosen D.S. 2002. A review of sea level monitoring status in Israel, in: Rosen D.S. and Thorkild A., editors: Intergovernmental Oceanographic Commission \& International Commission for the Scientific Exploration of the Mediterranean Sea MedGLOSS Pilot Network Workshop and Coordination Meeting, Israel Oceanographic \& Limnological Research, Haifa, 15-17 May 2000, IOC/UNESCO Report 176, 120pp.

Rosen D.S. 2002. Long term remedial measures of sedimentological impact due to coastal developments on the South-Eastern Mediterranean coast, Proc. Littoral 2002, The Changing Coast EUROCOAST/EUCC, Ed. EUROCOAST, paper 40, Vol 2., pp.322-331, Porto, Portugal, Sept. 2002.

Rosen D.S. 2004. Assessment of the impact due to sea level rise and wave climate change on the state of the Israeli beaches, in view of the monitoring activities performed by Israel Oceanographic \& Limnological Research in Israel and abroad, Beaches 2004, Yearly Journal of the Israel Society for the Protection of Nature, June 2004, 6p, (in Hebrew).

Rosen D.S. 2005. Summary of knowledge on the coastal processes and the influence of climate change on the state of the beaches and coastal cliffs towards setting of a national policy for the preservation of the beaches and coastal cliffs at the Mediterranean coast of Israel, IOLR report H42/2005, November 2005, Submitted to the Interministerial Commission on Coastal Cliffs Policy

Rosen D.S. 2009. Research on coastal cliffs and beach erosion in Israel, IOLR report H56/2009, September 2009.

Rosen D.S., and L. Vajda, 1978. Hadera offshore coal unloading terminal - Wave disturbance model investigation, Progress Report No. 5 - Hadera wind and wave climate (Analysis of field data), CAMERI, P. N. 32/78, Haifa, May 1978.

Rosen D.S., E. Kit, M. Vajda. 1980. Asessment of the coal spillage at the Hadera coal unloading terminal and the possibility of coal pollution of neighboring beaches, Special Symposium on Environmental Impacts of the Hadera Power Plant and Unprotected Coal Unloading Terminal, Hadera, February 1980 (in Hebrew), 15 pp.

Rosen D.S., E. Kit. 1981. Evaluation of the wave characteristics at the Mediterranean coast of Israel, Israel Journal of Earth-Sciences, Vol. 30, No. 4, August 1982, pp. 120-134.

Rosen D.S., M. Vajda. 1982. Sedimentological Influences Of Detached Breakwaters, Proceedings of the 18th International Conference on Coastal Engineering, Capetown, ASCE Publ., Vol. 2, Ch. 116, November 1982, pp. 1930-1949. 
Rosen D.S. 2000. Haifa Port Expansion Project, Environmental Impact Assessment, Haifa East B, Phase A (Partial Reclamation), Summary of the final reports on sedimentological models and other studies, Israel Oceanographic \& Limnological Research, Tel Shikmona, Haifa, HPEIA 38, IOLR Report H37/2000, December 2000

Rosen D.S., and S. Calderon. 2004. CEROSPIG - A Web Based Guide on Coastal Erosion Protection \& ICZM in the Mediterranean, Abst. Littoral 2004, Aberdeen, UK, Sept. 2004.

Rosen D.S., L. Raskin. 2004. Wind and wave effects on sea level measurements, Abst. ESEAS-RI Workshop on Sea Level Observation and Interpretation, Malta 1-3 Nov. 2004.

Rosen, D.S., Z. Rosentroub, L. Raskin. 2005. Bridging studies for the examination of the feasibility of building artificial islands, measurements, processing and analyses of wave and currents data off Tel Baruch during Oct. 2002-Jan 2004, assessment of the wave climate in the central coastal county region and processing and analysis of wave data from Haifa, Hadera, Ashdod and Ashkelon for the period April 2002-March 2004, IOLR report H23/2005, Haifa, May 2005.

Rosen D.S., A. Golan, L. Raskin. 2005. Bridging studies for the examination of the feasibility of building artificial islands, measurement, sedimentological monitoringin the coastal strip from south of Batyam to Poleg river mouth in the period fall 1997 until fall 2003. IOLR report H39/2005, Haifa, November 2005.

Rosen, D.S., B. Galanti, A. Golan, and L. Raskin. 2007. Policy document on the collapse of coastal cliffs, Assessment study on the expected changes until 2100 at the beach cliffs of the country under the influence of climate change via marine morpho-dynamic processes. Final report, IOLR Report H6/2007, October 2007 (in Hebrew).

Shoshany M., A. Golik, A. Degani, H. Lavee, G. Gvirtzman. 1996. New evidence for sand transport direction along the coastline of Israel, Journal of Coastal Research, Vol. 12, pp.311-325.

Silberman, A., S. Ilani, R. Calvo. 2006. Geomorphological-lithological mapping of the coastal strip of Israel (up to about $1 \mathrm{~km}$ east of the beach), Remarks and expanations on the map. Geological Survey of Israel. (in Hebrew).

Silvester R., and J.R.C. Hsu. 1997. Coastal stabilization, Adv. Ser. on Ocean Engineering, Vol 14, World Scientific, Singapore.

Small, C. and R.J. Nicholls. 2003. A global analysis of human settlement in the coastal zone, Journal of Coastal Research

Sommerfeld Barry G., N. C. Kraus, M. Larson. 1996. SBEACH-32 interface user's manual, Final Report TAMU-CC-CBI-95-12, Conrad Blucher Institute for Surveying and Science Texas A\&M University-Corpus Christi, USA, January 2006.

The Dutch/Israeli Steering Committee. 2000. Artificial Islands Off The Mediterranean Coast Of Israel, Feasibility R\&D Study (Phase 1), Final Report, The Ministry of National Infrastructures, Jerusalem.

Toms G., and G. van Holland. 1999. Assessment of morphological impacts due to the construction of artificial islands along the coast of Israel, Review and evaluation of three detailed schemes, WL| Delft Hydraulics, Final report, November 1999, Delft, The Netherlands.

UNEP. 2005. Assessing coastal vulnerability: developing a global index for measuring risk, 54p.

U.S. Army Engineer Research and Development Center. 2004. Coastal Engineering Manual, ver. 2.01 Professional Edition, Vicksburg, USA.

Van Rijn L.C. 1989. Handbook Sediment Transport by Currents and Waves, Delft Hydraulics, Rep. H 461.

Vellinga, P., C. Katsman, A. Sterl,J. Beersma, W. Hazeleger, J. Church, R. Kopp, D. Kroon, M. Oppenheimer, H.-P. Plag, S. Rahmstorf, J. Lowe, J. Ridley, H. von Storch, D. Vaughan, R. van de Wal, R. Weisse, J. Kwadijk, R. Lammersen, N. Marinova. 2009. Exploring high-end climate change scenarios for flood protection of the Netherlands, International Scientific Assessment carried out at request of the Delta Committee The Netherlands, Wageningen University and Research Centre / Alterra and the Royal Netherlands Meteorological Institute (KNMI) scientific report WR 2009-05, De Bilt, The Netherlands.

Veri-Tech, Inc. 2005. Coastal Engineering Design and Analysis System (CEDAS) ver 4.03 Pro, Vicksburg, Mississippi, USA.

Vermeer, M., and S. Rahmstorf. 2009. Global sea level linked to global temperature, PNAS Early Edition, www.pnas.org_cgi_doi_10.1073_pnas.0907765106

Wang, X., and V. Swail. 2006. Climate change signal and uncertainty in the projections of ocean wave heights, Climate Dynamics, 26, 109-126, (2006). 
Wang, X. L., F.W. Zwiers, V.R. Swail. 2004. North Atlantic Ocean Wave Climate Change Scenarios for the Twenty-First Century, Journal of Climate, 17, 2368-2383, (2004).

Waterman R.E., and P.T.A. Liesting. 2001. Integrated Coastal Policy via Building with Nature,.

Wei-Hock Soon W., S.H. Yaskell. 2003. The Maunder minimum and the variable Sun-Earth connection, World Scientific, N.J., USA, 278pp.

Whitehouse R. 1998. Scour at marine structures, Thomas Telford Publ., London UK.

Wiseman C., G. Hayati, S. Frydman. 1981. Stability of heterogeneous sandy coastal cliff, Proc. 10th Conf. Soil mechanics and foundation engineering, Stockholm, Sweden, AA Balkema Publ., Rotterdam 11/59: 568-574.

Wolf, J., and D.K. Woolf. 2006. Waves and climate change in the north-east Atlantic, Geophysical Research Letters, (2006).

Woodworth P.L., J.A. Lowe, T. Knutson, R.E. McDonald, K. McInnes, K. Woth, H. Von Storch, J. Wolf, V. Swail, N. Bernier, S. Gulev, K. Horsburgh, A.S. Unnikrishnan, J. Hunter. 2006. Past and Future Changes in Extreme Sea Levels and Waves, Position Paper in Proc. WCRP Workshop Understanding Sea-level Rise and Variability, UNESCO, Paris, 6-9 June.

Woolf, D.K., P.G. Challenor. and R. Cotton. 2002. Variability and predictability of the North Atlantic wave climate, Journal of Geophysical Research, 107(C10), (2002).

Zviely, D., M. Klein. 2004. Coastal cliff retreat rates at Beit-Yannay, Israel in the 20th century, Earth Surface Processes and Landforms, Vol. 29, 2004. 